[Vicino Oriente XX (2016), pp. 49-56]

\title{
A BRIEF NOTE ON THE YEMENITE CHAHĀR TTAQQ MAUSOLEUMS. THE CASE OF BARĀQISH
}

\author{
Maria Vittoria Fontana - Sapienza University of Rome
}

\begin{abstract}
The chahār țāq, a type of building frequently used as a mausoleum in Iran during the Islamic era, has an undeniable Iranian pre-Islamic origin, but its architectural form, together with its function as a mausoleum, crossed the Iranian border and was attested in Yemen too. The $17^{\text {th }}$-century chahār țāq mausoleum at Barāqish seem to be a specific choice, probably of a Shī '̄ matrix.
\end{abstract}

Keywords: Barāqish; Yemen; chahār țāq; Islamic; architecture

Barāqish is located about $30 \mathrm{~km}$ north of the Mā'rib dam and $190 \mathrm{~km}$ east of Șan 'à', in Yemen.

The city walls date back to the Minaean epoch, but their upper part was rebuilt in Islamic times (around 1200). They enclose a semicircular area of some four hectares, where a small Islamic mausoleum also stands (figs. 1-2). ${ }^{1}$

This mausoleum, built in local white stone, is very close to a circular tower with which, however, it has no connection. It has a square plan (each side is about $4 \mathrm{~m}$ externally) and a dome on four open pointed arches, for a total height of about $6 \mathrm{~m}$.

At a certain point in time some works were carried out, probably to prevent the collapse of the building. Two of the four doorways have been walled-up with the placement of a wall against the north side and part of the west side (figs. 3-4). A building made of very coarsely cut stones - now collapsed - had been raised on the west side, and both the latter and the mausoleum had been externally clad (see the detail in fig. 3, below). Internally a layer of mud coating was applied to the walls and dome in order to make them smooth and homogeneous (figs. 5-6).

\section{DESCRIPTION}

Exterior (figs. 2-3, 4). ${ }^{2}$ The base of the four ' $\mathrm{L}$ ' shaped pillars supporting the dome is constituted by a unique slab; the other masonry stones are cut coarsely, except for those that outline the arches and present very regular cuts. The arches of the doorways are double, the inner ones are recessed and smaller and rest on a stone cut like a bevelled impost. The keystones of these arches are small wedged fragments, positioned to offset the opposite slope of the voussoirs. The external transition is highlighted by an octagon. A rectangular niche is cut into the south side of the dome, in correspondence with the apex of the arch below. The walls and dome are covered with a layer of white plaster, the greater part of which has fallen away; above the apex of the arch of the main entrance (to the south) thicker plaster forms a crescent moon alim finial.

1 Just mentioned by Paolo Costa (1984, 255, pls. Vb-VIa-b; English repr. 1994, V/3, pls. Vb-VIa-b).

2 The reconstructing drawing (fig. 4) was made by Giuseppe Labisi whom I thank. 
An inscription is incised into the plaster, to the right of the latter: ${ }^{3}$

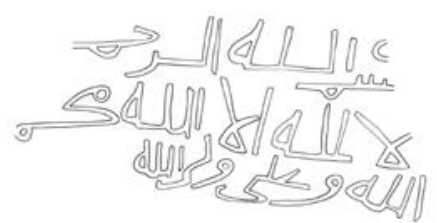

Drawing taken from a photo by Paolo Costa published in 1984 (C) M. Massullo, 2015).

In the name of God, the Compassiona[te, the Merciful] there is no God but Allāh. Muhamma[d is the messenger] of Allāh and 'Alī is the vicegerent of Allāh.

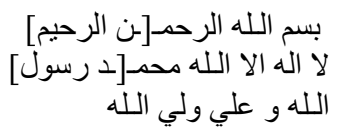

bismi-llāh al-rahm[an al-rahīm] là ila illà Allāh Muhamma[d rasūl] Allāh wa 'Al̄̄ walì Allāh

Interior (figs. 5-6). The internal transition between the square and the dome is achieved by four squinches constructed like those of Sarvistān, ${ }^{4}$ but each is framed by a doublepointed and projecting arch. The dome, preserved over the western half of the mausoleum, is composed of rings of pitched stones; these are set without mortar and are held in place by the lateral pressure they exert on one another. Apparently the first ring is composed of small stones laid like a sawtooth frieze, interrupted in correspondence with the keystones of the outer arches of the squinches, and interspersed with flat slabs. The second ring consists of flat slabs interspersed with very thin slabs placed over the flat slabs of the first ring only. The third ring, like all the following ones, is made up of stones of the same height but different sizes; however, unlike the other rings, stones are omitted in correspondence with the thin slab of the lower row, giving rise to small openings.

\section{PARALLELS}

As far as I know, mausoleums featuring the same shape are attested in Yemen in at least two other locations. There are twelve similar mausoleums in the cemetery west of Sa' $\mathrm{da}$, four of them bearing a fluted dome (fig. 7); they were built in stone and baked brick (the domes are made of bricks). Giovanna Ventrone Vassallo read the date found in the internal inscriptions of two mausoleums (both with a fluted dome): 970/1562 or 980/1572, and 1067/1656. ${ }^{5}$ There is another similar mausoleum in Ta izz, immediately east of the town, on the road before the Ibb- 'Aden crossroads (fig. 8); it was built in stone.

3 In the 1990s when I took my photos (fig. 2) only the last line of the inscription was visible. In a photo taken by P. Costa, published for the first time in 1984 (Costa 1984, pl. Vb; English repr. 1994, pl. Vb), three lines of the inscription are visible. They were reproduced in the drawing by Martina Massullo whom I thank.

4 For the squinches of Sarvistān palace, see Bier 1986, 42-43, with illustrations.

5 Ventrone Vassallo 1996, 52. 
This type of mausoleum recalls, in plan and elevation, the well-known chahār tāa (Persian; lit., four arches), a construction raised on the Iranian plateau in pre-Islamic times and built or re-used there in the Islamic period too. ${ }^{6}$

Among the famous Aswān mausoleums, in Egypt, reasonably dated to the $11^{\text {th }}-13^{\text {th }}$ centuries, ${ }^{7}$ there is a type (Type IIIA, according to Monneret de Villard, ${ }^{8}$ or Type IIA, according to Creswell, ${ }^{9}$ for a total of four mausoleums ${ }^{10}$ ), that can be included in the chahār țāq type. The latter, judged by Creswell as a prototype, ${ }^{11}$ could in all probability date back to the Fatimid period ( $11^{\text {th }}$ to early $12^{\text {th }}$ century).

\section{CONTEXT AND DATING}

The inscription above the main entrance of the Barāqish mausoleum, to the south, suggests a sure Shī' $\overline{1}$ context; indeed, Shī ìs often add "and 'Alī is the vicegerent of Allāh" to the shahäda. ${ }^{12}$ The current inscription, coarsely incised on the plastered surface of relatively recent date, most probably replaces the original one. I believe it is not unlikely that the original inscription, almost certainly on stone, i.e. a stele, containing the same words and possibly others (?), may have occupied the rectangular niche still visible on the southern side of the dome (figs. 2 and 4). This position is attested for the steles of mausoleums of this type in Aswān. ${ }^{13}$

The Shî $\overline{1}$ context ${ }^{14}$ of the Yemenite chahār tạq mausoleums suggests a dating for the Barāqish mausoleum to the late $16^{\text {th }}$ or, more likely, $17^{\text {th }}$ century, which is also supported by its masonry and elevation details.

6 See Huff 1975. On the debated question of the re-use of pre-Islamic buildings or of new buildings in the Islamic era in Iran, see also Grotti 2014. Among the Iranian chahār tāq mausoleums most probably re-used in Islamic times, we can mention the old chahār țāq in the Masjid-i Sha 'yā, in Ișfahān (Golombek 1974, 24, fn. 15, according to Siroux 1954, 2, fig. 2); among the new buildings, a chahār țāq at Zagh, north of Fīrūzābād, located in a cemetery (Huff 1975, 245, fig. 4), with four pointed arches (cf. Grotti 2014, 88).

$7 \quad$ Monneret de Villard 1930, 51; Creswell 1978, 137-138.

8 Monneret de Villard 1930, fig. 6; see also fig. 5 (mausoleum no. 17) and fig. 55 (mausoleum no. 33).

9 Creswell 1978, figs. 65-66.

10 Creswell 1978, 135, fn. 4.

11 Creswell 1978, 134-135.

12 This phrase is frequently attested from the Fatimid period onwards (Walker 2002, 96). Furthermore, Shī is extend the tașliyya, the statement of blessings on the Prophet, to include his family (Dammen McAuliffe 2006, 173).

13 «Essa [i.e. the "stele sepolcrale”] viene invece posta sopra l'apertura a sud, se il mausoleo ha tre o quattro aperture, in una nicchia» (Monneret de Villard 1930, 33). It is more difficult to suppose that the original inscription may have been inside the mausoleum, as in Șa da (cf. above).

14 See Stern 1951 and Sayyid 1974; see also Sayyid (ed.) 2002. 


\section{CONCLUSIONS}

The chahār țāq, a type of building frequently used as a mausoleum in Iran during the Islamic era, has an undeniable Iranian origin, but its architectural form, together with its function as a mausoleum, crossed the Iranian border and, starting from at least the $11^{\text {th }}$ century, was attested in Egypt. ${ }^{15}$ However, considering the wide multiplicity of shapes seen in the mausoleums in Aswān, the introduction of the chahār țāq type among the other ones does not seem particularly significant.

On the other hand, in Yemen the current twelve chahr țāq mausoleums of the western cemetery of Sa'da, where no other type is attested, are very interesting. Even the now isolated chahr țāq mausoleum at Barāqish, like that in Ta izz, seem to be as many examples of a specific choice, probably of a Shî $\overline{1}^{-1}$ matrix, ${ }^{16}$ conveniently 'competing' with the Sunnī Ottomans.

\section{REFERENCES}

BIER, L.

1986 Sarvistan. A Study in Early Iranian Architecture, London 1986.

Costa, P.

1984 Aspetti dell'insediamento urbano antico nella Penisola Araba: R. Traini (ed.), Studi in onore di Francesco Gabrieli nel suo ottantesimo compleanno, I, Roma 1984, pp. 253-260.

1994 Studies in Arabian Architecture (Variorum Collected Studies Series, CS 455), Norfolk 1994.

CRESWELL, K.A.C.

1978 The Muslim Architecture of Egypt, I. Ikhshīds and Fātimids A.D. 939-1171, New York 1978.

DAMMEN MCAULIFFE, J.

2006 The Cambridge Companion to the Qur'an, Cambridge 2006.

GOLOMBEK, L.

1974 Urban Patterns in Pre-Safavid Isfahan: Iranian Studies (Studies on Isfahan. Proceedings of the Isfahan Colloquium, Tehran, Part I) 7/1-2 (1974), pp. 18-44.

GRABAR, O.

1966 The Earliest Islamic Commemorative Structures: Ars Orientalis 6 (1966), pp. 7-46.

GROTTI, V.

2014 Il chahar taq e la sua evoluzione nell'architettura islamica dei territori iranici, MA Thesis, Sapienza University of Rome 2014 (unpublished).

HufF, D.

1975 "Sasanian” Čāhār Tāqs in Fārs: F. BAgherzadeH (ed.), Proceedings of the IIIrd Annual Symposium on Archaeological Research in Iran (2nd-7th November 1974), Tehran 1975, pp. 243-254.

15 It is now clear that in Egypt the mausoleum as a place of the 'cult of the saints' preceded the Fatimids and endured also after the end of their dynasty (see Taylor 1992, 8). As for a suggested significance of the Aswān mausoleums, see Grabar 1966, 25-26.

16 The Tayyibī da 'wa of the Sulaymānīs. 
MONNERET DE VILLARD, U.

1930 La necropoli musulmana di Aswān, Il Cairo 1930.

SAYYID, AYMAN FU'ĀD

$1974 \quad$ Sources de l'histoire du Yémen à l'époque musulmane, Le Caire 1974.

SAYYID, AYMAN FU'AD (ed.)

2002 The Fatimids and Their Successors in Yaman. The History of an Islamic Community, Arabic edition and English summary of Idrīs 'Imād al-Dīn's 'Uyūn al-akhbār, vol. 7, London - New York 2002.

SIROUX, M.

1954 La mosquée Sha ya et l'imam-zadeh Ismaël à Ispahan: Annales Islamologiques 1 (1954), pp. 1-51.

STERN, S.M.

1951 The Succession to the Fatimid Imam al-Āmir, the Claims of the Later Fatimids to the Rise TAYLOR, CH.S of Țayybī Ismailism: Oriens 4/2 (1951), pp. 193-255.

1992 Revaluating the Shi $i$ Role in the Development of Monumental Islamic Funerary Architecture: the Case of Egypt: Muqarnas 9 (1992), pp. 1-10.

VENTRONE VASSALLO, G.

1996 Les mausolées de la ville de Șa'da: J.-L. BACQUe-Grammont - A. TiBeT (eds.), Cimetières et traditions funéraires dans le monde islamique, Actes du Colloque International de la Recherche Scientifique (Istanbul, 28-30 septembre 1991), 2 vols, Ankara 1996, pp. 29-55.

WALKER, P.E.

2002 Exploring an Islamic Empire. Fatimid History and Its Sources, London 2002. 


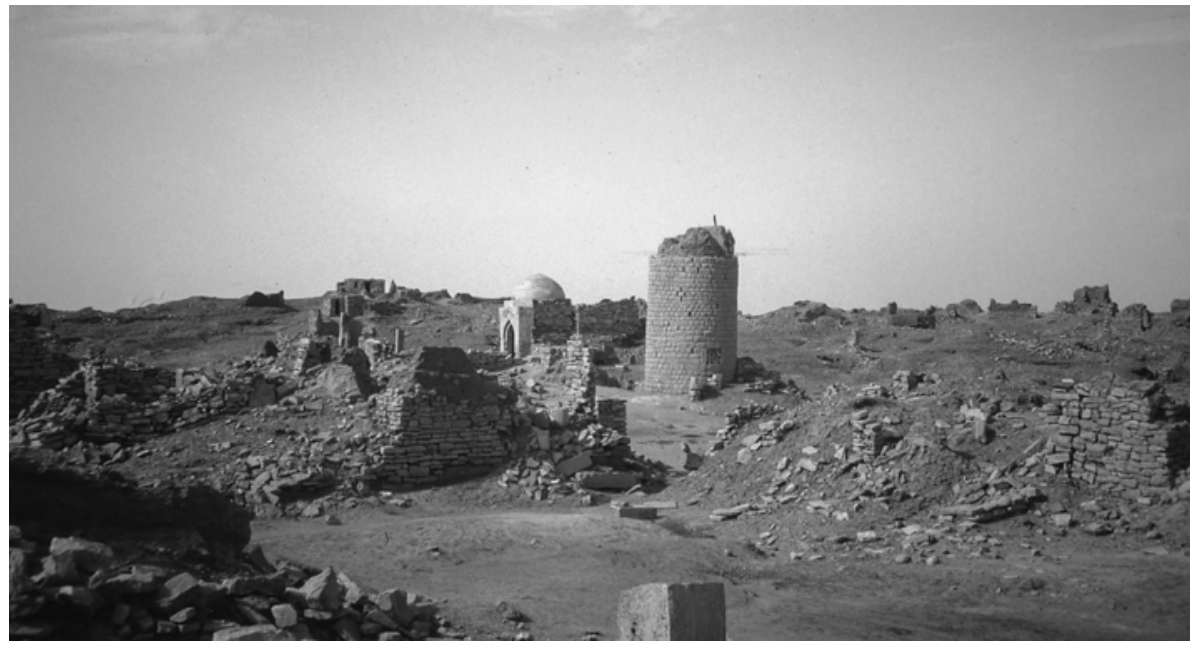

Fig. 1 - Barāqish. The chahār țāq mausoleum and a tower (C M.V. Fontana 1992).

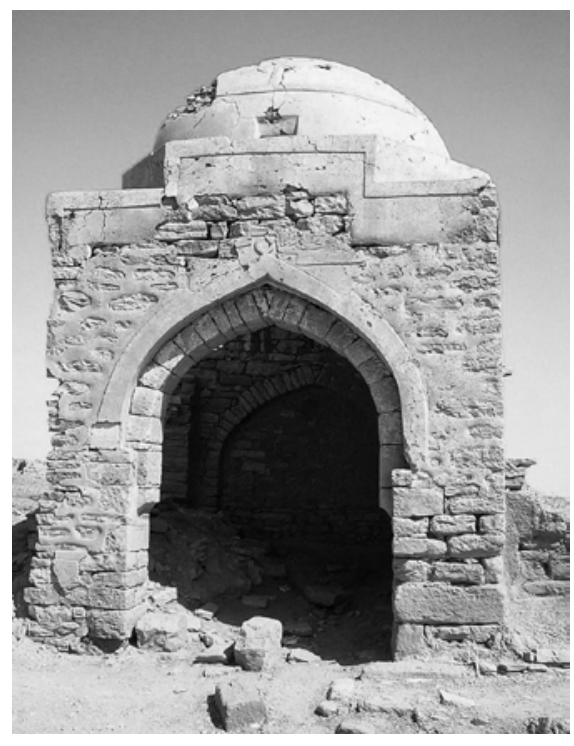

Fig. 2 - Barāqish. The chahār tāa mausoleum, south side: main doorway and inscription (C) M.V. Fontana 1993).

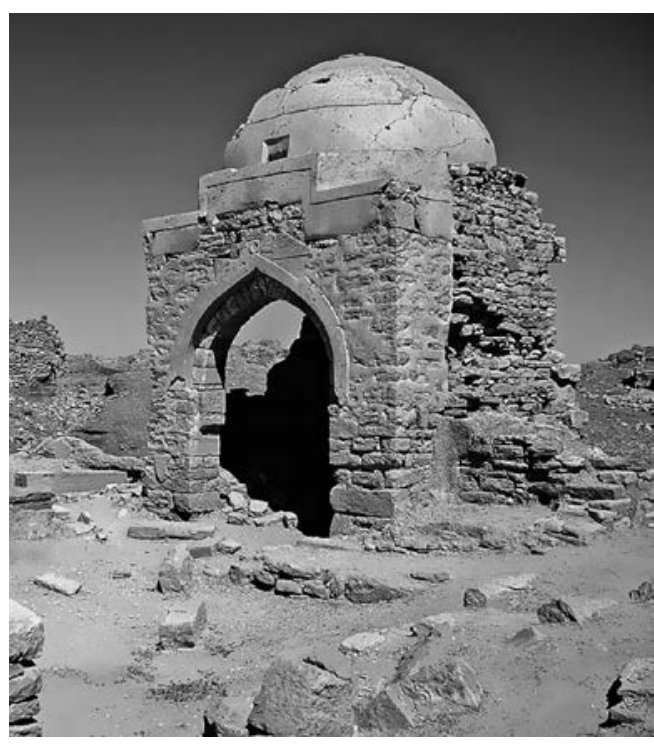

Fig. 3 - Barāqish. The chahār țāq mausoleum, south and west sides: a later building placed against the west side of the mausoleum (c M.V. Fontana 1993). 


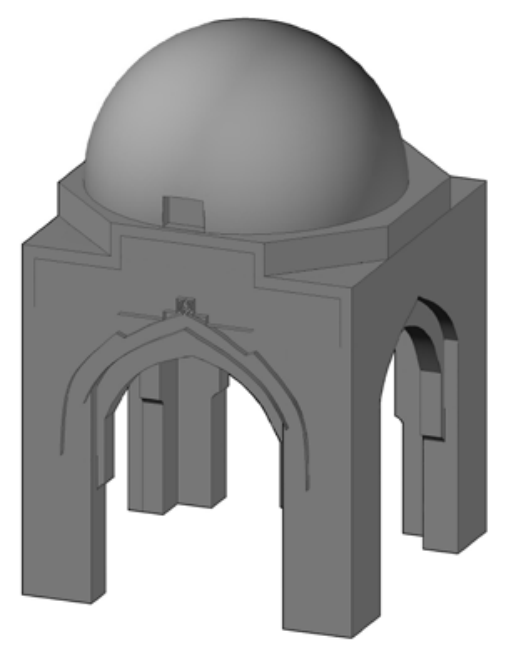

Fig. 4 - Reconstructing drawing of the exterior of the chahār țāq mausoleum at Barāqish (c G. Labisi 2015).

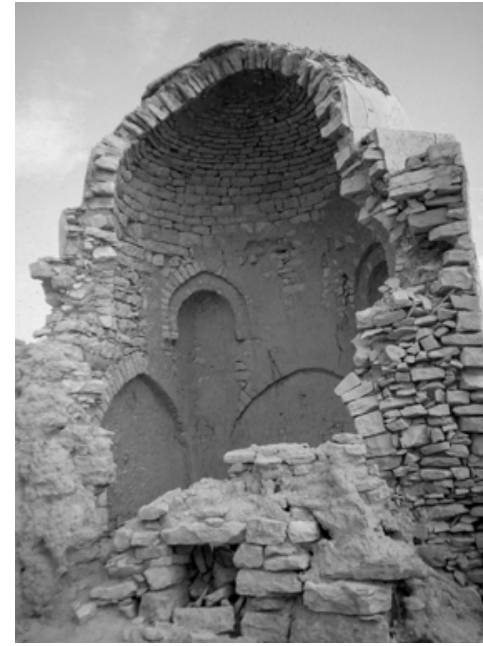

Fig. 5 - Barāqish. The chahār $t \bar{a} q$ mausoleum, west half: the interior, showing walled-up doorways, squinches and the dome (c M.V. Fontana 1992).

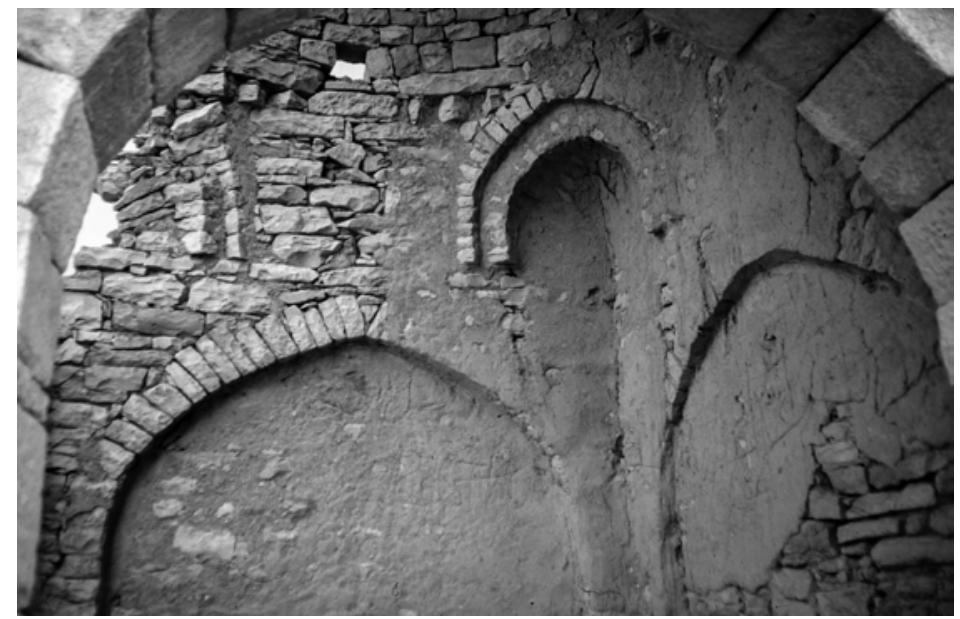

Fig. 6 - Barāqish. The chahār țāq mausoleum: the interior, showing a squinch and the lowest rings of the dome (๔ M.V. Fontana 1992). 


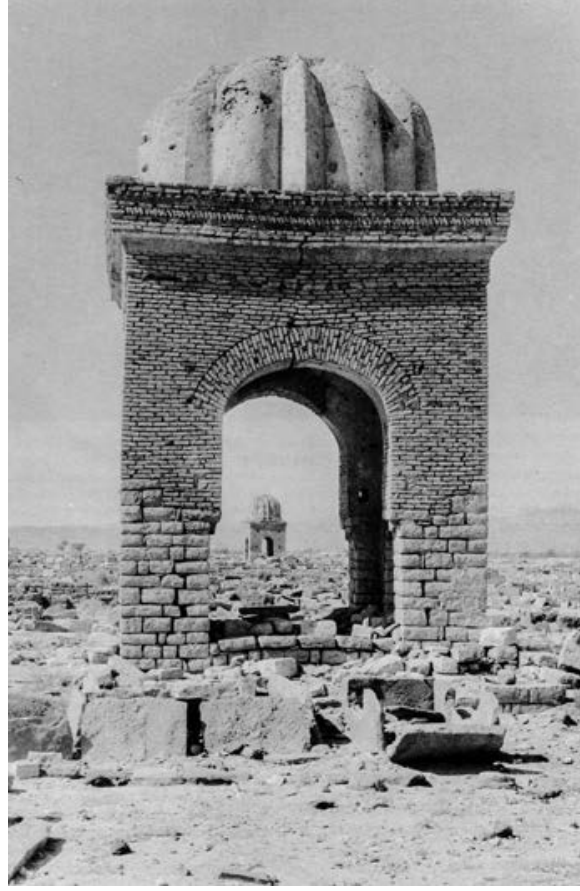

Fig. 7 - The cemetery west of Șa'da. Two chahār țāq mausoleums (Dep. CS 15942/11; C M. Jung 1985).

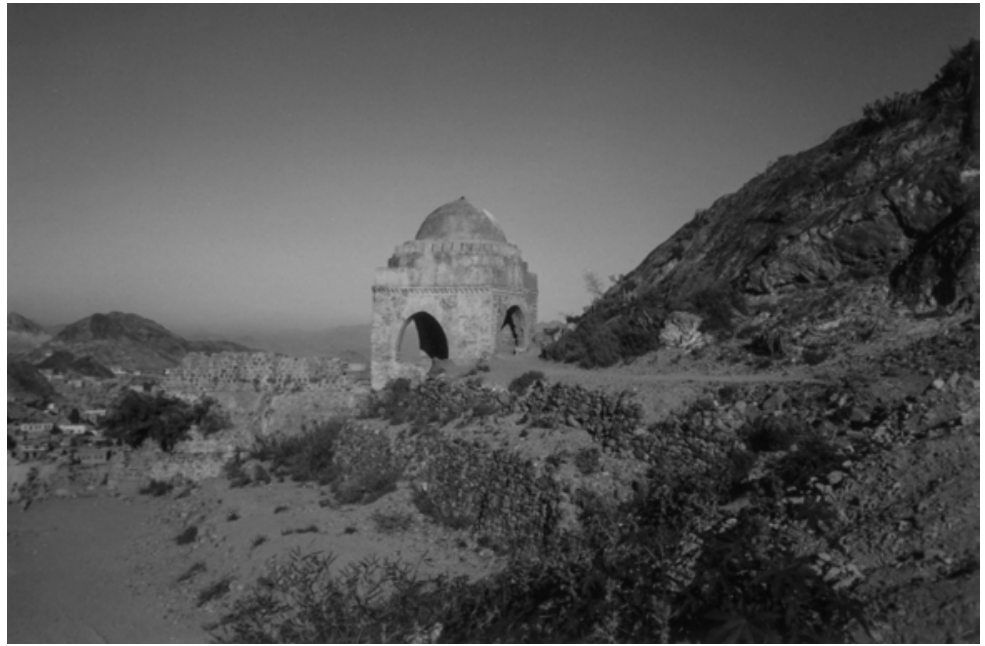

Fig. 8 - The road east of Ta'izz. A chahār tāa mausoleum (c) M.V. Fontana 1993). 